Article

ZOBIOLE, L.H.S. ${ }^{1 *}$

PEREIRA, V.G.C. ${ }^{2}$

ALBRECHT, A.J.P. ${ }^{2}$

RUBIN, R.S. ${ }^{1}$

ADEGAS, F.S. ${ }^{3}$

ALBRECHT, L.P. ${ }^{2}$

\section{Paraquat Resistance of Sumatran Fleabane (Conyza sumatrensis)}

Buva (Conyza sumatrensis) Resistente a Paraquat
ABSTRACT - In Brazil, some populations of Conyza bonariensis and C. canadensis are glyphosate resistant and there are populations of C. sumatrensis (Sumatran fleabane) presenting multiple resistance to both glyphosate and chlorimuron. During the 2014/2015 and 2015/2016 seasons, growers reported failures to control Sumatran fleabane with paraquat. This study investigated the potential of paraquat resistant Sumatran fleabane populations in Paraná state, Brazil. Populations with suspected paraquat resistance were tested in the field in 2016 season. In 2017, seeds from these populations were collected, sown and grown in a greenhouse. Paraquat doseresponse curve experiments were performed in Mogi Mirim, SP; Londrina, PR and Palotina, PR using doses of 0, 50, 100, 200, 400, 800, 1,600 and 3,200 $\mathrm{g} \mathrm{ha}^{-1}$, following all standard criteria for confirmation of weed resistance cases. Percentage control was assessed at 3, 7, 14, 21 and 28 days after application and data were fitted to a nonlinear, log-logistic model, and dose response curves were generated. The results of this study confirmed significant levels of resistance of Sumatran fleabane biotypes to paraquat with resistance factors between 3,57 to 34,29 . Therefore, the first case of C. sumatrensis resistance to paraquat was confirmed in biotypes from the western area of Paraná state, Brazil.

Keywords: control, dose-response, PSI inhibitor.

RESUMO - No Brasil, Conyza bonariensis e C. canadensis apresentam biótipos resistentes a glyphosate $\boldsymbol{C} \boldsymbol{C}$. sumatrensis apresenta resistência múltipla a glyphosate e chlorimuron. Durante as safras de 2014/2015 e 2015/2016 foram relatadas falhas no controle de buva submetida à aplicação de paraquat. Este estudo teve por objetivo investigar a possibilidade da resistência ao paraquat em populações de C. sumatrensis. Populações com suspeita de resistência foram testadas em campo na entressafra de 2016, sendo depois coletadas sementes e plantas durante a safra de 2017, que foram posteriormente, estudadas em casa de vegetação. Experimentos com curva de dose-resposta foram instalados em Mogi-Mirim, SP, Londrina-PR e Palotina-PR, utilizando doses de 0, 50, 100, 200, 400, 800, 1.600 e $3.200 \mathrm{~g} \mathrm{ha}^{-1}$. Foi avaliada a porcentagem de controle aos 3, 7, 14, 21 e 28 dias após aplicação e utilizado um modelo não linear log-logístico para o ajuste da curva de doseresposta. Com os resultados obtidos neste estudo, foi confirmada a hipótese inicial do primeiro caso de resistência da buva ao paraquat na região oeste do Estado do Paraná, com fator de resistência variando entre 3,57 e 34,29, seguindo todos os critérios para a confirmação da resistência.

Palavras-chave: controle, dose-resposta, inibidor do fotossistema I.
Copyright: This is an open-access article distributed under the terms of the Creative Commons Attribution License, which permits unrestricted use, distribution, and reproduction in any medium, provided that the original author and source are credited.

${ }^{1}$ Corteva Agriscience ${ }^{\mathrm{TM}}$, Agriculture Division of DowDuPont ${ }^{\mathrm{TM}}$, Barueri-SP-Brasil; ${ }^{2}$ Universidade Federal do Paraná, PalotinaPR, Brasil; ${ }^{3}$ Embrapa Soja, Londrina-PR, Brasil. 


\section{INTRODUCTION}

Conyza sp. is an annual dicot weed that often emerges in the autumn and winter (Tozzi and van Acker, 2014). In Brazil, the winter fallow period (May to September) corresponds to the emergence peak of Sumatran fleabane; this period allows the plant to grow undisturbed in fallow and reach sizes where control with herbicides becomes very difficult (Oliveira Neto et al., 2010). Such biological characteristics, agronomic practices, and the selection for herbicideresistant biotypes contribute to the wide expanding areas of Conyza populations (Dauer et al., 2009).

In Brazil, populations of $C$. bonariensis, $C$. canadensis have been selected for glyphosate resistant and populations of $C$. sumatrensis can exhibit multiple resistance to both glyphosate and chlorimuron (Santos et al., 2014; Heap, 2017). In this genus, there are also several cases of resistance to other herbicide modes of action such as photosystem I inhibitors worldwide. There are many countries where Conyza sp. has been reported to be resistant to paraquat since 1980, e.g., Hungary (Pölös et al., 1987), Taiwan, Japan, Egypt, Malaysia, Canada, Unites States, Belgium, Sri Lanka, South Africa; the last report in 2016 was in Australia (Chiang and Chiang, 2006; Heap, 2017; Preston, 2017).

Paraquat remains important as a preplant burndown herbicide as it is one of only three herbicide active ingredients (the other two being glyphosate and glufosinate) that are truly nonselective, broad spectrum, and without residual soil activity (Hawkes, 2013). Non-selective herbicides such as paraquat are widely used in no-till systems to control weeds prior to planting. Emerged Conyza requires a burndown application utilizing paraquat, sometimes in a sequential program that utilizes sequential preplant application combinations of glyphosate $+2,4-\mathrm{D}$ followed by paraquat (Oliveira Neto et al., 2010; Oliveira Jr. et al., 2013).

In the western region of Parana State, in the 2014/2015 season, farmers reported failure to control Conyza sp. following typical paraquat applications. In this case, the applications normally occurred in the fall, by spraying a split program ("double shot") using glyphosate + 2,4-D or glyphosate + chlorimuron followed by a sequential application of paraquat. A similar situation occurred in the 2015/2016 season, with reduced efficacy of the sequential application of paraquat. Further in the 2016/17 season, there were several reports by farmers to external consultants and researchers, regarding control failures and increased tolerance of Conyza to paraquat in some agricultural fields located near Palotina and Assis Chateaubriand. Therefore, the aim of this research was to test and evaluate the presence of resistance to paraquat in these Sumatran fleabane populations.

\section{MATERIAL AND METHODS}

\section{First experiment - preliminary investigation}

In 2016, growers reported failures to control paraquat using the commercial label rate at $400 \mathrm{~g} \mathrm{ha}^{-1}$, applied in burndown prior soybean sowing. The location was a soybean field located in Assis Chateaubriand-PR $\left(2^{\circ} 16^{\prime} 53.8^{\prime \prime S} 53^{\circ} 30^{\prime} 47.5^{\prime \prime W}\right)$. In the same area, a strip test using a $\mathrm{CO}_{2}$ pressurized backpack sprayer ( $2 \mathrm{~m}$ boom) was performed, spraying paraquat at the same rate used by farmers. No symptoms were noted. Thus, in November 2016, live plants of C. sumatrensis ( $6 \mathrm{~cm}, 8$ leaves) were collected randomly in the areas of fields where the postemergence paraquat treatment did not provide control. These plants were taken to the greenhouse of Federal University of Paraná (UFPR), located in Palotina-PR, Brazil.

The plants were transplanted to pots $\left(5 \mathrm{dm}^{-3}\right)$ and irrigated twice a day under greenhouse conditions; day/night temperatures were set at $25 \pm 5^{\circ} \mathrm{C} / 16 \pm 5^{\circ} \mathrm{C}$ with no supplemental lighting. Approximately five weeks after being transplanted, the plants reached $12 \mathrm{~cm}$ height and had 10-12 leaves. The first experiment was conducted to evaluate the level of control after paraquat application.

The experimental design was a randomized complete block with three replications. The treatments were a commercial formulation of registered paraquat $\left(200 \mathrm{~g} \mathrm{~L}^{-1}\right.$, Paraquate ALTA 200 SL, trademark of ALTA - América Latina Tecnologia Agrícola Ltda) at 800 and 1,600 $\mathrm{g} \mathrm{ha}^{-1}$ 
mixed with the adjuvant Agral at $0.1 \%(\mathrm{v} / \mathrm{v})\left(\right.$ Agral $^{\circledR}$, trademark of Syngenta Crop Protection, Greensboro, NC) and an untreated group without herbicide. The recommended label rate to control Conyza sp. ranges between 300 and $400 \mathrm{~g}^{\text {ha }}{ }^{-1}$, depending on the manufacturer (SEAB, 2017). Herbicide applications were made with a $\mathrm{CO}_{2}$ pressurized backpack sprayer fitted with four XR-110015 flat-fan nozzles (TeeJet Technologies, Wheaton, IL) at a pressure of $240 \mathrm{kPa}$ and a speed of $1 \mathrm{~ms}^{-1}$, delivering an application volume equivalent to $200 \mathrm{~L} \mathrm{ha}^{-1}$.

Control percentage (visual scale from 0 to 100\%) was assessed at 14 and 28 days after application according to SBCPD (1995). The results were submitted to analysis of variance (F) and treatments were considered significantly different when probability was less than $5 \%$ $(p \leq 0.05)$. When the F-test was significant, Tukey's test at $5 \%(P \leq 0.05)$ was used for comparisons of means.

\section{Second experiment}

In March 2017, the F1 generation seeds from the previous experiment were collected, which were sent to three different locations for greenhouse studies. Three experiments were conducted simultaneously in Londrina-PR (Embrapa Soja) - Biotype 1 (B1), in Palotina-PR (Universidade Federal do Paraná-UFPR) Biotype 2-3 (B2-B3) and in Mogi Mirim-SP (Mogi Mirim Field Station, Dow AgroSciences) - Biotype 4 (B4). Seeds for the susceptible biotypes were collected in PalotinaPR, Londrina-PR and Mogi Mirim-SP in areas without known issues to control using the herbicide paraquat, in order to understand the level of susceptibility of such species.

The experimental units were $1.0 \mathrm{dm}^{-3}$ pots containing common planting mix substrate. The seeds were sown and after emergence were thinned to one seedling per pot. Plants at the reproductive stage were properly identified anatomically by Professor Jimi Naoki Nakajima in the Biology Institute (INBIO) of the Universidade Federal de Uberlandia-MG (UFU), although more studies have been conducted to properly confirm the species.

Treatments were sprayed on Sumatran fleabane when the plants reached $10 \mathrm{~cm}$ of height and had 8-10 leaves. The registered herbicide in use was paraquat $\left(200 \mathrm{~g}\right.$ a.i. $\mathrm{L}^{-1}$, Paraquate ALTA 200 SL, a trademark of ALTA - América Latina Tecnologia Agrícola Ltda) associated with the adjuvant Agral at $0.1 \%(\mathrm{v} / \mathrm{v})\left(\mathrm{Agral}^{\mathbb{}}{ }\right.$, a trademark of Syngenta Crop Protection, Greensboro, $\mathrm{NC}$ ) at 0, 50, 100, 200, 400, 800, 1,600 and 3,200 $\mathrm{g} \mathrm{ha}^{-1}$. All herbicide applications were made with a $\mathrm{CO}_{2}$-pressurized backpack sprayer using the same settings as in the first experiment. The experimental design was a randomized complete block with five replications.

Unlike the first experiment, efficacy was assessed visually as control percentage $(0=$ no effect, $100=$ complete control) at 3, 7, 14, 21 and 28 days after application of paraquat. Plants were considered to be alive when green tissue was present. Dry weight evaluation was performed at 28 days after herbicide applications. The plants were clipped at the soil surface, placed in paper bags, and oven dried at $70{ }^{\circ} \mathrm{C}$ for 4 days, and weight was then recorded. The dose response curves were performed with the biotype that presented the least control relative to the susceptible biotype.

Data were submitted to analysis of variance and regression analysis, and when significant, they were adjusted to logistic nonlinear regression model proposed by Streibig (1988):

$$
y=\frac{a}{\left[1+\left(\frac{x}{b}\right)^{c}\right]}
$$

where: $y$ is the response variable, $a$ is the amplitude between the maximum and minimum point of the variable, $x$ is the dose of the herbicide $\left(\mathrm{g} \mathrm{ha}^{-1}\right), b$ is the dose that promotes $50 \%$ response of the variable, $c$ is the declivity of the curve around $b$.

The logistic nonlinear model provides an estimate of the parameter $\mathrm{C}_{50}$ or $\mathrm{GR}_{50}$. In this way, a decision was made to use the mathematical calculation through the inverse equation of Streibig 
(1988), hence $\mathrm{C}_{50}$ could be calculated according to the proposition of Souza et al. (2000). The models used to obtain $\mathrm{C}_{50}$ were the same ones used in other recent reports cited in the literature (Takano et al., 2016, 2017).

$$
x=b\left(\left|\frac{a}{y}-1\right|\right)^{\frac{1}{c}}
$$

With the values for $\mathrm{C}_{50}$ and $\mathrm{GR}_{50}$, we calculated the resistance factor (RF) resulting from the difference between $\mathrm{C}_{50}$ or $\mathrm{GR}_{50}$ of the possible resistant population and $\mathrm{C}_{50}$ or $\mathrm{GR}_{50}$ of the susceptible population.

\section{RESULTS AND DISCUSSION}

\section{First experiment}

The results found with the first experiment, using paraquat at 800 and $1,600 \mathrm{~g} \mathrm{ha}^{-1}$, showed that the level of control of resistant C. sumatrensis was poor, providing less than $10 \%$ control at 14 and 28 DAA, and there was no statistical difference between the two doses applied (Table 1). In Brazil, the registered commercial label rate used of paraquat to control Conyza bonariensis is $400 \mathrm{~g} \mathrm{ha}^{-1}$ (SEAB, 2017), although there is no substantial difference to control other species, such as Conyza summatrensis or Conyza canadensis, using such rate. In the literature, susceptible

Table 1 - Control of resistant Conyza summatrensis at 14 and 28 days after application. Palotina-PR

\begin{tabular}{|c|c|c|c|c|}
\hline \multirow{2}{*}{ Treatment } & \multirow{2}{*}{ Active ingredient } & \multirow{2}{*}{$\begin{array}{c}\text { Rate } \\
\left(\mathrm{g} \mathrm{ha}^{-1}\right)\end{array}$} & 14 DAA & \% Control \\
\cline { 3 - 5 } & & 800 & $6.3 \mathrm{a}$ & $4.0 \mathrm{a}$ \\
\hline 1 & Paraquat & 1600 & $7.7 \mathrm{a}$ & $4.7 \mathrm{a}$ \\
\hline 2 & Paraquat & - & $0.0 \mathrm{~b}$ & $0.0 \mathrm{~b}$ \\
\hline 3 & Untreated & & 3.14 & 2.27 \\
\hline HSD $(\mathrm{p} \leq 0.05)^{*}$ & & & 1.08 & 0.78 \\
\hline Standard deviation & & & 23.15 & 27.06 \\
\hline
\end{tabular}

Means within a column followed by the same letter are not significantly different according to Tukey's HSD (honest significant difference) at $\mathrm{P} \leq 0.05$. DAA $=$ days after application.

biotypes of $C$. bonariensis can be $100 \%$ controlled when sprayed with paraquat at $400 \mathrm{~g} \mathrm{ha}^{-1}$ (Vargas et al., 2007). Such result was found for plants at the 4-leaf growth stage. However, Yamauti (2010) found $84 \%$ control when they sprayed paraquat at $600 \mathrm{~g} \mathrm{ha}^{-1}$ to C. canadensis and C. bonariensis.

The results of the preliminary study in the first experiment indicated a high level of resistance to paraquat and motivated the collection of $\mathrm{F} 1$ seeds to create a more robust dose-response analysis in further experiments.

\section{Second experiment}

The analysis of the dose response experiments, from the adjusted non-linear model utilizing the equation proposed by Streibig (1988), enabled the adjusted curves for the variables analyzed, with $\mathrm{R}^{2}$ being close to 1.00 . Thus, the parameters $\mathrm{a}, \mathrm{b}$ and $\mathrm{c}$ of the equation could be determined, allowing the calculation of the paraquat dose required to control $50 \%$ of the population evaluated $\left(\mathrm{C}_{50}\right)$ for control at $28 \mathrm{DAA}$, as well as the dose required to reduce weight by $50 \%\left(\mathrm{GR}_{50}\right)$ of all biotypes with suspected resistance. Table 2 shows the values of $\mathrm{C}_{50}, \mathrm{GR}_{50}$ and resistance factor $(\mathrm{RF})$ for both variables of all tested biotypes. 
Table 2 - Rate of paraquat required to control $50 \%$ of the population (28 DAA), to reduce shoot dry weight by $50 \%$ and resistance factor (RF) for populations of Conyza sumatrensis. 2016/2017

\begin{tabular}{|c|c|c|c|c|}
\hline \multirow{3}{*}{ Population } & $\mathrm{C}_{50}$ & RF & $\mathrm{GR}_{50}$ & RF \\
\hline & \multicolumn{2}{|c|}{ Control } & \multicolumn{2}{|c|}{ Dry weight } \\
\hline & \multicolumn{4}{|c|}{$\left(\mathrm{g} \mathrm{ha}^{-1}\right)$} \\
\hline Susceptible - Londrina (PR) & 60 & - & 60 & - \\
\hline Londrina $(\mathrm{PR})-\mathrm{B} 1$ & 1844 & 31 & 2007 & 33 \\
\hline Susceptible - Palotina (PR) & 63 & - & 67 & \\
\hline Palotina (PR) - B2 & 913 & 14 & 244 & 3.6 \\
\hline Palotina (PR) - B3 & 2468 & 39 & 1166 & 17 \\
\hline Susceptible - Mogi Mirim (SP) & 54 & - & 20 & - \\
\hline Mogi Mirim (SP) - B4 & 1491 & 28 & 699 & 34 \\
\hline
\end{tabular}

$\mathrm{C}_{50}$. dose of paraquat required to control $50 \%$ of the population; $\mathrm{GR}_{50}$ - dose required to reduce weight by $50 \%$. $\mathrm{RF}-$ resistant factor.

In general, for all susceptible biotypes, $\mathrm{C}_{50}$ ranged between 54 to $63 \mathrm{~g}^{\text {ha }} \mathrm{g}^{-1}$ and $\mathrm{GR}_{50}$ from 20 to $67 \mathrm{~g} \mathrm{ha}^{-1}$ (Table 2). These results provided high $\mathrm{RF}$, as in Londrina, PR, $\mathrm{C}_{50}$ for the $\mathrm{B} 1$ at $28 \mathrm{DAA}$ was $1844\left(\mathrm{~g} \mathrm{ha}^{-1}\right)$ and $\mathrm{GR}_{50}$ was $2007\left(\mathrm{~g} \mathrm{ha}^{-1}\right)$, demonstrating a RF for control of 31 and RF for dry weight of 33. In Palotina, PR (B2 and B3) showed $\mathrm{C}_{50}$ of 913 and 2468 (g ha ${ }^{-1}$ ) and RF of 14 and 39, respectively. In addition, $\mathrm{GR}_{50}$ was 244 and $1166\left(\mathrm{~g} \mathrm{ha}^{-1}\right)$ for B2 and B3, providing a RF of 3.6 and 17. The same results were found for the B4 population in Mogi Mirim, SP which had $\mathrm{C}_{50}$ and $\mathrm{GR}_{50}$ of 1491 and $699\left(\mathrm{~g} \mathrm{ha}^{-1}\right)$ respectively, with a RF to control of 28 and 34.

Moretti et al. (2013) found similar $\mathrm{GR}_{50}$ values to those found in this study in paraquatresistant C. bonariensis. However, $\mathrm{GR}_{50}$ of paraquat varied across seasons $(940,240$ and $70 \mathrm{~g}$ a.i. ha ${ }^{-1}$ during summer, fall, and winter, with a RF of 33, 22, and 6 times higher than the resistant population, respectively). Turcsányi et al. (1998) found different levels of resistance factors according to stage of weed development, and the resistant factor to paraquat in C. canadensis ranged from 450 at the vegetative rosette stage to 1000 at the flowering stage.

In paraquat, cationic amino acid transporters (CAT) were hypothesized to be involved in paraquat sequestration into the vacuole based on the transcription increase of a certain CAT gene in a C. canadensis resistant biotype (Jóri et al., 2007). However, it is not currently known what the mechanism of resistance is in this case, five possible mechanisms of resistance have been proposed: (a) altered compartmentation of paraquat; (b) restricted cuticular penetration; (c) detoxification of reactive forms of $\mathrm{O}_{2}$ produced in the presence of paraquat; (d) inactivation of paraquat through plant metabolism and (e) sequestration of paraquat, preventing translocation to the site of action (Fuerst and Vaughn, 1990). There is a case of resistant to paraquat in Solanum nigrum, in which the possible mechanism of resistance is due to reduced electron flow in PSI (Chase et al., 1998).

In all biotypes, $\mathrm{RF}$ was greater than $1(\mathrm{RF}>3.0)$. The dose response curves are shown in Figure 1. Although the four biotypes tested in this study had been collected in the same location, they showed differential response to paraquat, and RF ranged from 3.6 to 34 . The results confirmed the initial suspicion of the presence of paraquat-resistant biotypes in the western region of Paraná, after the experiments had followed the criteria for confirming a new case of herbicide resistance of weeds according to HRAC, (2017); Criterion 1: definition of weed resistance: the plants from these populations have survived and reproduced after their exposure to a herbicide dose that was lethal to the susceptible population; Criterion 2: confirmation by defined protocols in the scientific base: the resistance factors were higher and the recommended dose to the species (400 $\left.\mathrm{g} \mathrm{ha}^{-1}\right)$ did not provide satisfactory control; Criterion 3: characterization of heritability: the F1 plants from these populations were also considered to be resistant; Criterion 4: demonstration of the practical impact in the field by the herbicide resistant weed: control flaws complaints were clearly observed on the field; Criterion 5: botanical identification: random plants of these populations were properly classified as C. sumatrensis. 
(A)

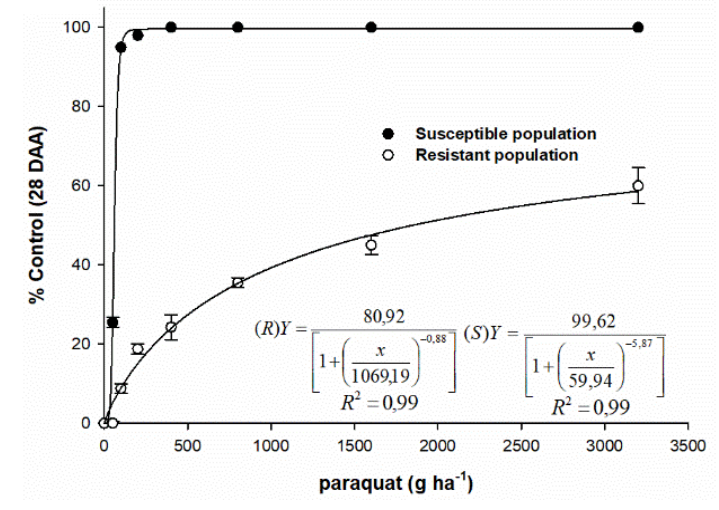

(C)

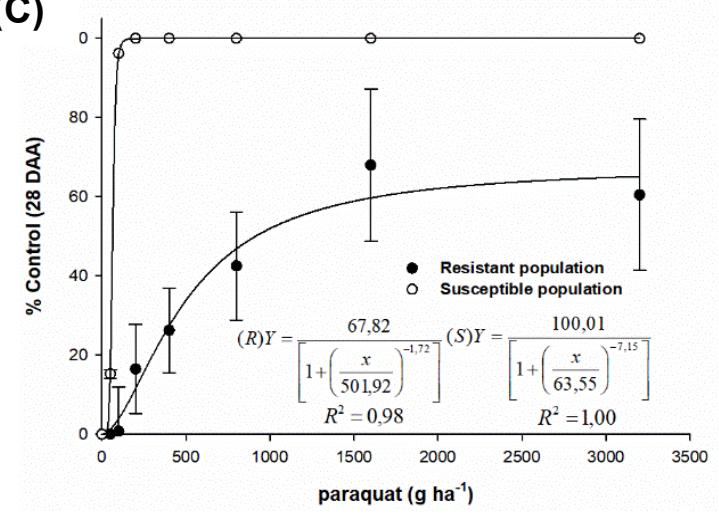

(E)

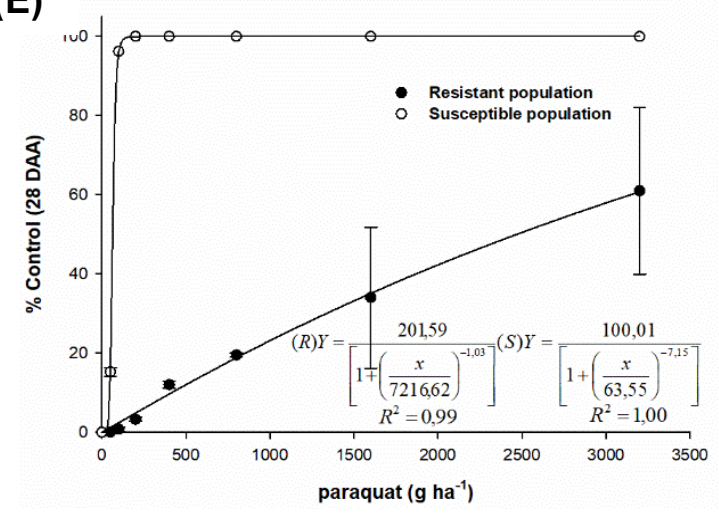

(G)

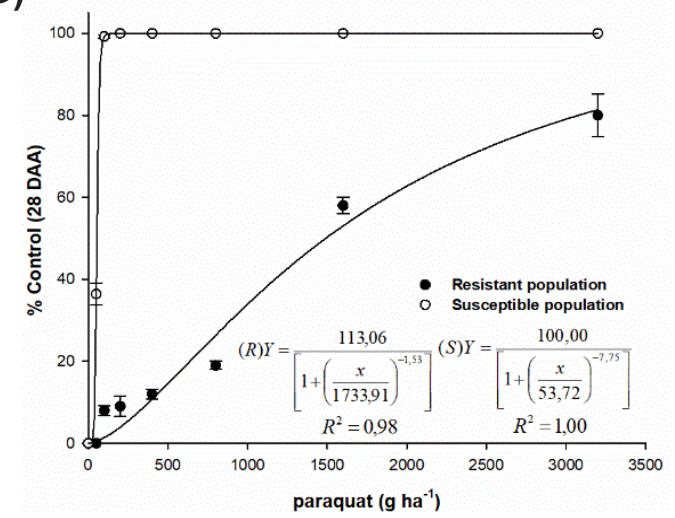

(B)

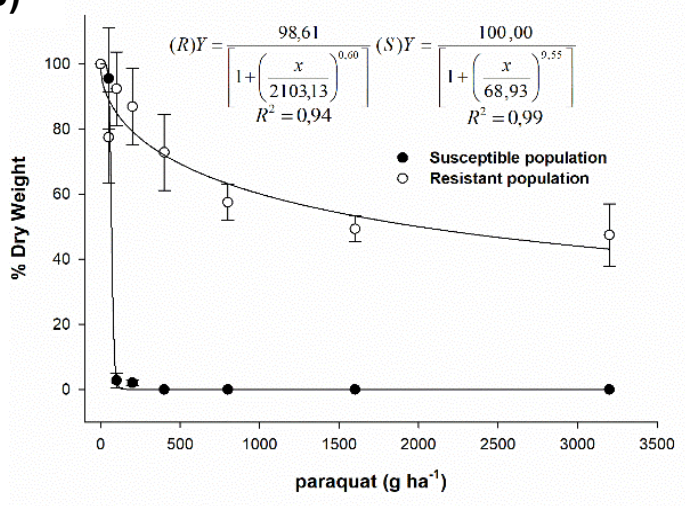

(D)

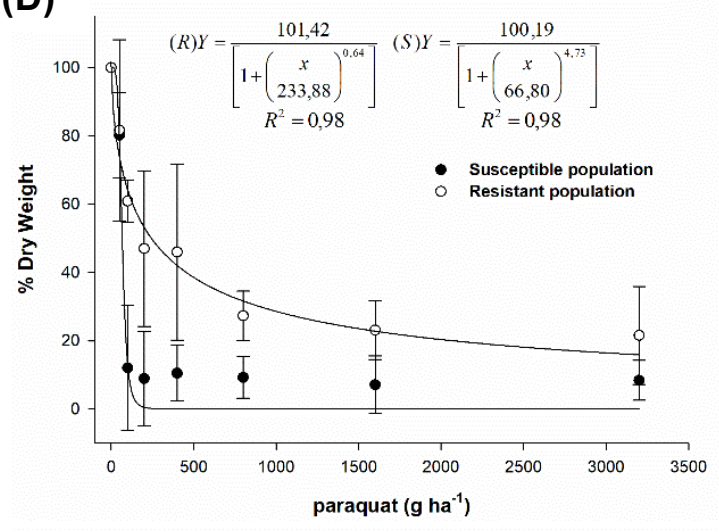

(F)

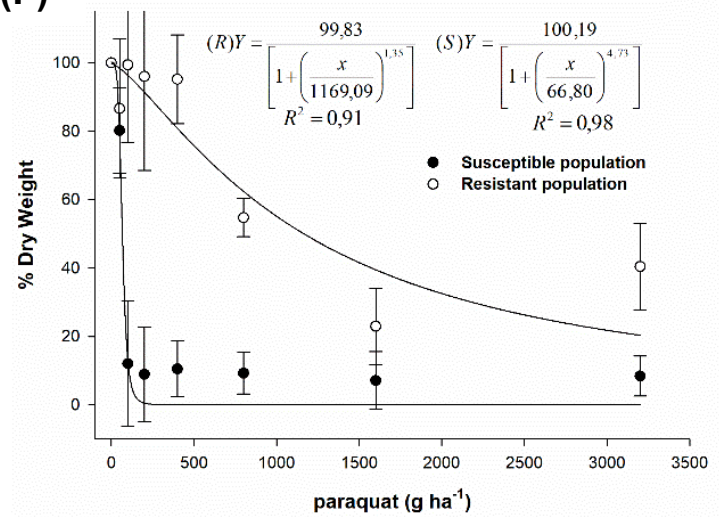

(H)

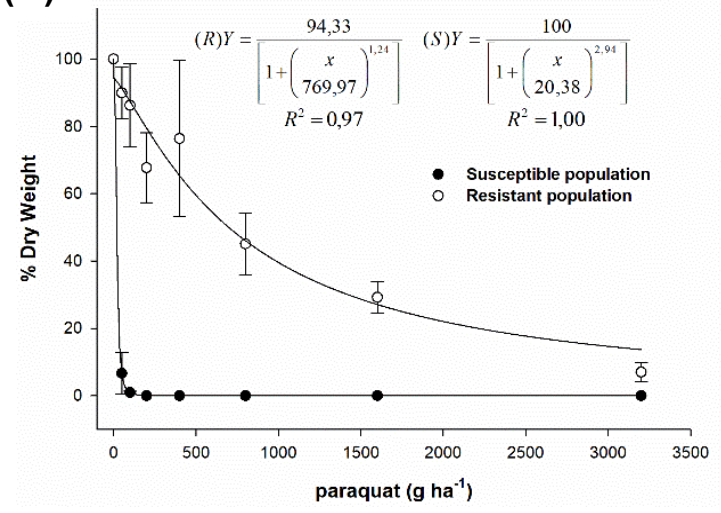

Figure 1 - Percent control (A, C, E G) and dry weight (B, D, F, H) at 28 DAA in Londrina-PR (A,B) Palotina-PR (C, D, E, F) and Mogi Mirim-SP (G, H), respectively. 
Based on the results found in this study, the initial hypotheses were confirmed that this report is the first case of Sumatran fleabane resistance to paraquat in Brazil. Further studies should be conducted to understand the mechanisms that lead to resistance to paraquat.

\section{ACKNOWLEDGEMENTS}

We would like to thank Professor Jimi Naoki Nakajima (UFU), who properly identified the Conyza species; Greice Jacomini, who supported seed collection in the field during the studies; Marcelo Augusto Reinert and Cleber Paludo, who supported the monitoring of the area where the plants and seeds used in this study were collected; and Cristian Natalino Zanfrilli de Souza, who helped to conduct the experiments.

\section{REFERENCES}

Chase CA, Bewick TA, Shilling DG. Characterization of paraquat resistance in Solanum americanum Mill. II. Evidence for a chloroplast mechanism. Pestic Biochem Physiol. 1998;60(1):23-30.

Chiang YJ, Chiang MY. Handbook on herbicides and framland weeds in Taiwan. Taiwan: Agricultural Chemicals and Toxic Substances Research Institute, Council of Agriculture, Executive Yuan; 2006. (in Chinese).

Dauer JT, Mortensen DA, Luschei EC, Isard SA, Shields E, Van-Gessel MJ. Conyza canadensis seed ascent in the lower atmosphere. Agric For Meteorol. 2009;149(3-4):526-34

Fuerst EP, Vaughn KC. Mechanism of paraquat resistance. Weed Technol. 1990;4:150-6.

Hawkes RT. Mechanisms of resistance to paraquat in plants. Pest Manag Sci. 2013;70:1316-23.

Heap I. International survey of herbicide-resistant weeds. [accessed on: 01 May 2017] Available in: http://www.weedscience.org.

Herbicide Resistance Action Commitee - HRAC. [accessed on: 10 Aug 2017] Available in: http://www.hrac-br.com.br/arquivos/ criteriosrelatos.pdf

Jóri B, Soós V, Szegõ D, Páldi E, Szigeti Z, Rácz I, et al. Role of transporters in paraquat resistance of horseweed (Conyza canadensis (L.) Cronq). Pestic Biochem Physiol. 2007;88:57-65

Moretti LM, Hanson BD, Hembree KJ, Shrestha A. Glyphosate resistance is more variable than paraquat resistance in a multipleresistant hairy fleabane (Conyza bonariensis) population. Weed Sci. 2013;61(3):396-402.

Oliveira Jr RS, Guerra N, Osipe JB, Franchini LHM, Adegas FS, Osipe R. Herbicidas registrados para uso e resultados de pesquisa. In: Constantin J, Oliveira Jr RS, Oliveira Neto AM, editores. Buva: Fundamentos e recomendações para manejo. Curitiba: Omnipax; 2013. Cap.7. p.65-90.

Oliveira Neto AM, Constantin J, Oliveira Jr RS, Guerra N, Dan HÁ, Alonso DG, et al. Estratégias de manejo de inverno e verão visando ao controle de Conyza bonariensis e Bidens pilosa. Planta Daninha. 2010;28(Esp.):1107-16

Pölös E, Mikulas J, Szigeti Z, Laskay G.Cross-resistance to paraquat and atrazine in Conyza canadensis. Proceedings of the British Crop Protection Conference-Weeds. Surrey:1987. p. 909-916.

Preston C. The Australian Glyphosate Sustainability Working Group. Online. Internet. [acsessed on: 15 May 2017] Available at: http://www.glyphosateresistance.org.au

Santos G, Oliveira Jr RS, Constantin J, Francischini AC, Osipe JB. Multiple resistance of Conyza sumatrensis to chlorimuron ethyl and to glyphosate. Planta Daninha. 2014;32(2):409-16.

Sociedade Brasileira da Ciência das Plantas Daninhas - SBCPD. Procedimentos para instalação, avaliação e análise de experimentos com herbicidas. Londrina: 1995. 42p.

Secretaria da Agricultura e do Abastecimento do Paraná - SEAB. Faça sua pesquisa. SEAB. 2017. [acessado em: 01 maio 2017] Disponível em: http://celepar07web.pr.gov.br/agrotoxicos/pesquisar.asp 
Souza AP, Ferreira FA, Silva AA, Cardoso AA, Ruiz HA. Uso da equação logística no estudo de dose-resposta de glyphosate e imazapyr por meio de bioensaios. Planta Daninha. 2000, 18:17-28.

Streibig JC. Herbicide bioassay. Weed Res. 1988;28:479-84.

Takano HK, Oliveira Jr RS, Constantin J, Braz GBP, Gheno EA. Goosegrass resistant to glyphosate in Brazil. Planta Daninha. 2017;35:2-9.

Takano HK, Oliveira Junior RS, Constantin J, Braz GBP, Franchini LHM, Burgos NR. Multiple resistance to atrazine and imazethapyr in hairy beggarticks (Bidens pilosa). Cienc Agrotec. 2016;40(5):548-54.

Tozzi E, van Acker RC. Effects of seedling emergence timing on the population dynamics of horseweed (Conyza canadensis var. canadensis). Weed Sci. 2014;62:451-6.

Turcsányi EG, Turcsányi E, Darkó É, Borbély G, Lehoczki E. The activity of oxyradical-detoxifying enzymes is not correlated with paraquat resistance in Conyza canadensis (L.) Cronq. Pestic Biochem Physiol. 1998;60:1-11.

Vargas L, Bianchi MA, Rizzardi MA, Agostinetto D, Dal Magro T. Buva (Conyza bonariensis) resistente ao glyphosate na região sul do Brasil. Planta Daninha, 2007;25(3):573-8.

Yamauti MS, Yamauti MS; Barroso AAM, Souza MC. Controle químico de biótipos de buva (Conyza canadensis e Conyza bonariensis) resistentes ao glyphosate. Rev Cienc Agron. 2010;41(3):495-500. 